\title{
FINDINGS FROM A MOBILE TABLET PROJECT IMPLEMENTATION IN RURAL SOUTH AFRICA
}

\author{
Marlien Herselman ${ }^{1,2}$, Adele Botha ${ }^{1,2}$, Sifiso Dlaminii ${ }^{1}$, Mario Marais ${ }^{1}$ and Nare Mahwai ${ }^{1}$ \\ ${ }^{I}$ CSIR, P.O. Box 395, Pretoria, South Africa \\ ${ }^{2}$ University of South Africa, School of Computing, Florida Campus, South Africa
}

\begin{abstract}
The purpose of this paper is provide evidence of how the selected teachers at 24 schools in 7 provinces in South Africa reacted to questions pertaining to the extent of their prior training, attitudes towards technology, perceived self-confidence in integrating ICTs and finally using ICTs on a daily basis. The project is known as the Information Communications Technology for Education (ICT4E) project, funded by the Department of Rural Development and Land Reform (DRDLR) in South Africa, where teachers were trained in seven of the nine provinces in South Africa over a period of a year and a half to integrate mobile technology to support their teaching and learning at 24 schools. This project involved 197 teachers and 6895 learners. The methodology that was applied is a sequential explanatory mixed method approach where data was collected using firstly a survey (baseline survey), followed by one-to-one interviews. Data was analyzed using descriptive statistics (quantitative data) as well as coding through Nvivo (quantitative data). The main results indicated that more females $(65.5 \%)$ than males were involved. Teachers mostly received training on the basics of computers in Education and are mainly using word processors for their work purposes. The average age of the teachers are 43 years and their mother tongue is mostly Setswana $(21 \%)$. In general, they indicated a positive attitude towards getting training to use the mobile tablets but they did worry about their competence and knowledge in resolving technical issues if these may occur with the tablets. A high percentage indicated they use social media (96\%) and 92\% indicated that their schools have banned the use of a mobile phone. $95.4 \%$ of teachers felt comfortable to use a tablet to enhance their teaching and learning and they can teach in more effective ways $(98 \%)$. The teachers were convinced $(2 \%)$ that the mobile device will assist the learners to learn more.
\end{abstract}

\section{KEYWORDS}

Teacher's Perception, Mobile Tablets, Teacher Professional Development, Rural Schools, Attitude and Experience in Mobile Technology

\section{INTRODUCTION}

In February 2016, the Council of Science and Industrial Research (CSIR) in Pretoria, South Africa, signed a Project Specific Agreement with the Department of Rural Development and Land Reform (DRDLR) for implementing the DRDLR ICT for Education Project (ICT4E) over a period of three years. The aim is to integrate mobile technology into schools to facilitate improvement to the quality of teaching and learning, the scope of the DRDLR ICT4E Project covers(Botha \& Herselman, 2018) amongst other things a focus on providing Teacher Professional Development through accredited training materials.

For the purpose of this paper the focus will be on baseline survey that was applied prior to the teacher training in order to understand their level of computer literacy, their experience with using and applying ICTs in the classrooms (if at all), and their attitude towards using mobile tablets. What they used a mobile phone mostly for was also assessed. The baseline provided an overview and a basic understanding of the teacher's responses on different concepts related to ICT integration in education.

Schools and more specifically rural schools in South Africa are battling to try and implement the White Paper on e-education (Department of Basic Education, 2004), especially at organizational level (Kotzé, Van der Westhuizen \& Barnard, 2017; Vandeyar, 2010). This is mainly the case as the translation of national policies to provincial policy still needs to be determined coupled with contextual issues.

Research question of this paper is: What evidence can be provided on teacher's perceptions of using mobile technology in their classrooms before given training on using the devices? 
The focus is specifically on rural schools in resource constrained environments as these schools are influenced by other dimensions than urban schools. These schools face more challenges when implementing mobile technology, like the lack of internet access, lack of funding, geographical location and electricity. These schools are also sometimes referred to as resource constrained as access to basic resources are a challenge. According to Botha and Herselman (2016) a resource constrained context where rural schools are found is regarded as a place where low income communities reside and bandwidth is also a challenge. Other constraints in this type of context can include cultural issues and people are usually not familiar with or have an anxiety to use technology. Power and connectivity are also sometimes non-existing (Adukaite, van $\mathrm{Zyl}, \mathrm{Er}$ \& Cantoni, 2017).

\section{TEACHER SKILLS AND COMPETENCE TO USE TECHNOLOGY}

To invest in the training of teachers, is regarded as much more important than to invest in technology (Vosloo, 2010). Teachers are increasingly expected to have skills to apply technology to support learning (Botha, Herselman, Musgrave \& Jaeschke, 2017). This requires teachers to take advantage of the power of emerging technology to design and deliver education to promote learners' understanding of concepts and to develop learners' digital literacy. Investing time and money to improve teachers, and teaching, is viewed by members of School Governing Bodies (SGBs) as pivotal (Botha et al., 2017). For this to happen teachers have to be trained to apply and develop content of a digital nature and to use technology in their specific subject areas (Ekanayake \& Wishart, 2014).

Teacher support improves practice (Botha \& Herselman, 2015). Lack of adequate and ongoing school support influences the acceptance and adoption of mobile devices in teaching (Chiu \& Churchill, 2016).

Teachers also have individual, and collective, responsibility for their own professional development. Teachers have to take charge of their own self-development by identifying areas in which they need to develop and to seize opportunities that are available to them through various forums such as the South African Council for Teachers (SACE), which is the teachers' own professional body, and the Integrated Quality Management System (IQMS)(Department of Basic Education, 2007).

The White Paper on e-education (Department of Education, 2004), was the first example of how the South African government envisaged the use of ICT should be applied in education in 2004. ICT was regarded as a resource for whole school development to improve productivity, management and administration; curriculum integration and delivery, communication and teacher and learner collaboration (Mabila, Van Biljon \& Herselman, 2017). When ICTs are implemented in schools, it can support literacy skills but also allow for teachers to change their thinking, values, emotions (especially anxiety) and attitudes regarding the integration of mobile devices into teaching (Chiu \& Churchill, 2016).

There are numerous examples of mobile technology integration projects to support teaching in South Africa (d'Aiglepierre, Aubert \& Loiret, 2017; UNICEF, 2017; Meyer, Marais \& Dlamini, 2016; Smore, 2016; Kukulska-Hulme, 2007; Thornton \& Houser, 2005). There are also educational platforms available in SA to support teaching and learning like Thutong (Department of Basic Education, 2012). Other platforms supporting mobile integration in schools are hosted by organizations like Mindset Learn and digital classrooms of Vodacom (Mabila et al., 2017). Projects that are supporting mobile specifically in South Africa is the provincial government department projects such as the Gauteng and North-West tablet projects as well as subject specific projects such as the Teaching Biology and MoMaths projects (Kruger, 2015).

\section{TEACHER'S BELIEFS AND ATTITUDES TO USE TECHNOLOGY IN THEIR CLASSROOMS}

The beliefs, attitudes and anxiety levels of teachers when integrating mobile technology into their classrooms are important to consider (Blackwell, Sheridan, Instone, Schwartz \& Kogan, 2009; Kim, Holmes \& Mims, 2005). It is for teachers more important to experience how to use the technology and to know how to integrate it to support various teaching methods (Şad \& Göktaş, 2014; Ertmer, Ottenbreit-Leftwich, Sadik, Sendurur \& Sendurur, 2012). Therefore, it is necessary to develop programmes that support ICT literacy skills. Especially if strategies can be included to nurture the desired changes in teachers' thinking, values and 
attitudes and insights into how anxiety can be limited when integrating mobile devices into teaching (Chiu \& Churchill, 2016; Teo, Lee \& Chai, 2008).

Teachers need to be trained to effectively use educational learning applications to teach various curricula. Professional learning communities, which enable teachers to collaborate and share best practices and integrate 21st century skills into classroom practice, should also be supported (Mabila et al., 2017; Haßler, Major \& Hennessy, 2016). It is here where mentorship programmes, which provide support for implementation can be applied and assistance can be provided to teachers. Especially when they have to determine which applications to select to support their specific subject content (Kruger, 2015).

Even if there are concerns about the integration of technology into educational settings (Bates, Swennen \& Jones, 2014), it is believed that with the support of adequate leadership and the potential of digital content to support teaching, these challenges can be counteracted (Terhoven \& Fataar, 2018; Rikkerink, Verbeeten, Simons \& Ritzen, 2016). Thoughtfulness, creativity and commitment to sustain specific action plans are required to successfully integrate technology to support teaching (Naiman, 2016). Successful integration of mobile technology to support collaborative learning has also been indicated by Fu and Hwang (2018) and explained by Hwang, Chu and Lai (2017) when a mobile learning project was conducted in Taiwan.

In order to eliminate poverty, reduce inequality and spur economic development, South Africa's National Development Plan (NDP) identifies education, training, life-long learning and innovation as key priorities(National Planning Commision, 2011). The four major features supported by the E-education policy framework for the use of ICT in teaching and learning are: equity, access to ICT infrastructure, capacity building and norms and standards (Mabila et al., 2017). Education systems must change to facilitate mobile access to education and one of the most important changes is training teachers to prepare them for the mobile world (Ally, 2009). The infrastructure of a school is also important for teachers to motivate them to teach, as some schools, especially in rural areas of South Africa lack basic equipment like desks and many computer facilities at these schools are under-serviced and dysfunctional (Terhoven \& Fataar, 2018). Better qualified teachers move to better equipped schools where there is adequate infrastructure, buildings, electricity, lavatories, learning materials and resources, as these factors directly affect teachers' and learners' performances (Ramorola, 2018) (Khumalo, Molepo \& Mji, 2015). In a recent report of the OECD (OECD, 2018) it was indicated that Education has a vital role to play in developing the knowledge, skills, attitudes and values that enable people to contribute to and benefit from an inclusive and sustainable future. Learning to form clear and purposeful goals, work with others with different perspectives, find untapped opportunities and identify multiple solutions to big problems will be essential in the coming years.

The challenges of the educational school system in South Africa should be underestimated as conditions in which teachers work are complex due to the pervasive legacies of South Africa's history (Ramorola, 2018). The subsequent changes in policies and implementation that have occurred since the dawn of democracy in 1994, did result in different education departments (Mabila et al., 2017).

Efforts have been made to rationalise the education system into a single national system, and teachers have had to cope with the changes amid other challenges, as new curricula have been introduced (Terhoven $\&$ Fataar, 2018). Teachers therefore face many challenges in schools in South Africa (Ramorola, 2018).

Based on these challenges of rural schools, the DRDLR has decided to invest in these communities throughout South Africa by providing infrastructure and training to teachers to use the infrastructure (mobile tablets, servers and learner tablets). Before the project could commence it was important to determine where the pre-selected teachers are regarding their digital literacy skills, their attitude as well as experience with technology integration in classrooms. This knowledge informed the development of the specific training modules that was provided by the University of the Free State or UFS (they won the tender to train).

\section{TEACHER PROFESSIONAL DEVELOPMENT IN ICT4E PROJECT}

The CSIR was given the mandate by the DRDLR to develop a baseline survey as part of the monitoring and evaluation from the initiation of the DRDLR ICT4E project. The DRDLR selected the schools and 10 teachers from each school. Therefore, a total of 240 teachers were initially enrolled to take part in TPD. Each teacher received a pre-loaded (apps and training material) mobile tablet (Android) for the training and use in schools to support their teaching and learning. The TPD training commenced in the afternoons, for four (4) hours after school hours. TPD training is divided into six separate sessions of two consecutive days each. The 
teachers are expected to do Reflective Journals $1-3$ to be submitted during Session 2 (visit 2), session 4 and after session 5 but before session 6 (the $3^{\text {rd }}$ one will not be marked but teachers need to hand it in to be competent). The teacher will complete and hand in 2 assignments - and hand them in at session 3 and session 5. This information was part of the baseline survey and communicated to all teachers and principals involved by both the CSIR and UFS before training started.

TPD involves accredited training by University of the Free State (UFS), where teachers have enrolled as students at the UFS and received student numbers. Teachers are expected to commit themselves to attend at least $90 \%$ of the training sessions. These teachers also receive homework and are assessed in order to qualify to receive the accredited certificate in TPD for Digital Mobile Learning Certificate, if they meet all the required criteria. Successful participants may then apply for recognition of prior learning for advanced standing/credit transfer towards the introduction to the ICT module as part of the Advanced Certificates in Teaching offered by the UFS. The way teachers are accredited and trained also involved gamification elements and this motivated them all to attend these sessions amidst other challenges (time, new curriculum and large classes).

\section{METHODOLOGY}

A sequential, explanatory mixed methods approach was followed where the use of both the qualitative and quantitative research methods in a singular study is applied (Creswell \& Clark, 2017). In this paper, this method was applied to collect and analyses data. Integration of the two forms of data provided a more robust understanding of the research problem than a singular approach would have done (Creswell \& Poth, 2017). Out of the six types of mixed methods designs observed by Creswell and Clark (2017), this study used the sequential explanatory design (Quan followed by Qual). In qualitative data analysis, the overall inferences and meaning of data are considered to be more important than the meaning of its parts (Creswell, Hanson, Clark Plano \& Morales, 2007). Quantitative data (from the survey), on the other hand, is analyzed using statistical and mathematical techniques in order to observe specific variables in a data set (Mouton, 2006). The thematic analysis of qualitative data (from one-to-one interviews was carried out using the Nvivo software version 11 (NVIVO, 2017). The data analysis for the quantitative phase of the survey was conducted using the SPSS version 24. The data analysis consisted of both descriptive and inferential statistics (Cronbach's alpha and t-tests).

Triangulation of both the qualitative and quantitative data will be used to establish reliability and validity of the components of the model. Triangulation is done to ensure that the research design is strengthened and also to increase the ability to interpret the findings. Using more than one data method allows the finding from one method to be corroborated or questioned by comparison with data from another method.

The baseline survey covered five areas: Demographics, prior training of the teachers, the ICTs that teachers use mostly on a day-to-day basis, information about the attitude of teachers towards using technology in their classrooms and finally teachers self confidence level to integrate technology into their classroom. The interviews also focused on the same five areas in order to determine more information directly from the teachers to support the survey data.

\section{RESULTS}

From the 240 teachers who started as part of this project only 197 teachers from all the 24 schools in the 7 provinces completed the baseline questionnaire. The baseline was done by the Monitoring and Evaluation team of the CSIR (all could speak the specific mother tongue languages of a specific area). Every teacher involved were assisted if any questions were raised or if there was any misinterpretation of specific questions. More primary than secondary schools were involved. Ethical approval was received to conduct this assessment and thus each teacher completed an informed consent form which outlined that all information will be confidential. 
A summary of the results is reflected below:

Section A covered the demographics and revealed the following results:

A third (34.5\%) of the participants was male and $65.5 \%$ female; the ages ranged from 22 to 64 years and the average age of the group of teachers was 43 years; three-quarters of the teachers $(74 \%)$ had a Bachelor's or higher degree; a quarter of the teachers lived in the Northern Cape; and the five languages spoken by teachers represented the most were SeTswana (21\%), Afrikaans (20\%), isiXhosa (16\%), isiZulu (15\%), Sepedi (14\%). The provinces where the schools were situated consisted of Limpopo, Gauteng, Free State, Northern Cape, North West, Eastern Cape and Kwa- Zulu Natal. Mphumalanga and Western Cape were not involved.

This data was also confirmed during the interviews.

Section $B$ covered prior training of the teachers and revealed the following results (Figure 1):

Most of the teachers ( $82 \%)$ did receive basic introduction to computer training. The use of word processors were also recorded at $67 \%$. Low percentages were found regarding their knowledge on technical supporting themselves when problems occur (18\%), as well as knowledge of ICT leadership and managing ICTs in schools (9\%).

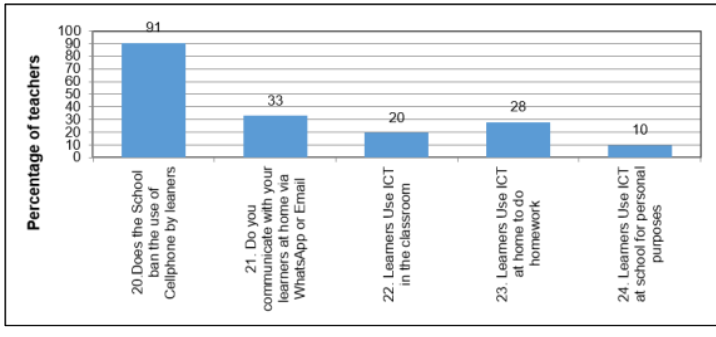

Figure 1. Prior experience of teachers on ICT Training

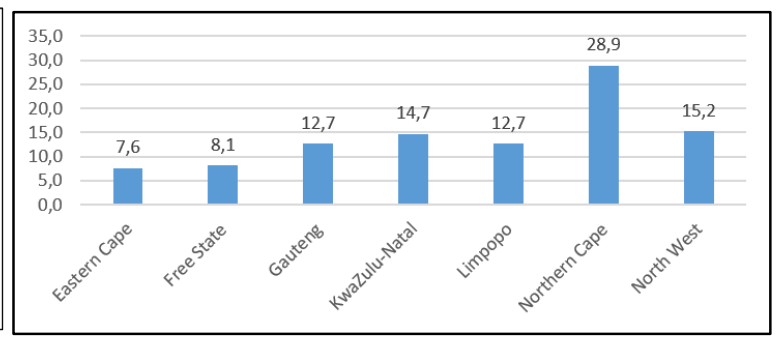

Figure 2. ICTs teachers mostly use of a daily basis

A stepwise multiple regression analysis was performed to evaluate the contributions of the different items in the battery of items to the scale on exposure to prior training. At step 1 of the analysis 'Basic Usage of ICTs in Education' entered into the regression equation and was significantly related to the scale on 'exposure to prior training', $\mathrm{F}(1,195)=215.49, \mathrm{p}<.000$. The multiple correlation coefficient was 0.73 , indicating approximately $52.5 \%$ of the variance of the scale: 'exposure to prior training' could be accounted for by 'Basic Usage of ICTs in Education' (Adjusted R² $=0.525, \mathrm{p}<.001$ ).

Section C covered the ICTs that teachers use mostly on a day-to-day basis and revealed the following results (Figure 2):

- $92 \%$ access social networking platforms from their own mobile phones and not from computers at school or at home

- $75 \%$ do email also via their mobile phones whilst $21 \%$ do this form a computer at home

- $63 \%$ do mobile banking using their mobile phones

- Mobile phones are mostly used for taking photos (98\%) and video recordings (88\%) and accessing Apps $(87 \%)$

- Typing exam papers (52\%) and recording marks (74\%) and school administrative tasks (69\%) are mostly done at computers at schools.

- When involving learners via ICT at schools $90.6 \%$ indicated that schools ban the use of mobile phones by learners at schools.

Section D provided information about the attitude of teachers towards using technology in their classrooms:

$95.4 \%$ of teachers felt comfortable to use a tablet to enhance their teaching and learning and they can teach in more effective ways (98\%); $50.3 \%$ indicated that they will not be able to fix anything if something goes wrong on their tablets; $95 \%$ were excited to use a tablets in their classrooms and $98 \%$ indicated that the tablets is a valuable tool for a teachers to use in their classrooms and it will change the way they teach (98.9\%); The tablet will change the way their learners learn in class $(98.2 \%)$ and learners will find it easy to use $(92 \%)$. 
Section $E$ covered the teachers self confidence level to integrate technology into their classroom and the following graph indicates that they are very confident:

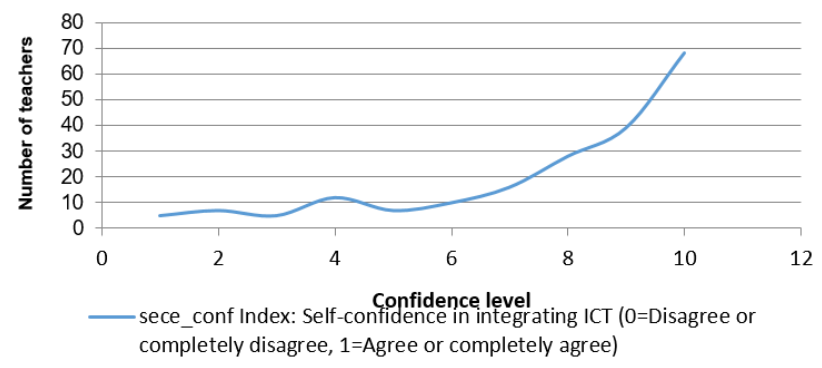

Figure 3. Teacher's self confidence levels regarding ICT use

Most teachers also indicated that they will need support to select appropriate technology or software to support them in teaching with the tablets and that they can learn quickly to adapt to new technology (49\%) but $60 \%$ felt that their digital literacy levels mostly bad when it comes to technical skills to solve problems.

The sixth scale or indicator represents the teachers' responses on a Likert rating scale of 1 to 10 to the statement: "I think my level of digital literacy is...". Descriptive statistics on the scales are provided in Table 1.

Table 1. Descriptive statistics of the developed scales

\begin{tabular}{|c|c|c|c|c|c|}
\hline Scale/ Indicator & $\mathrm{N}$ & Minimum & Maximum & Mean & $\begin{array}{l}\text { Std. } \\
\text { Deviation }\end{array}$ \\
\hline Prior training & 197 & -1.16192 & 2.80758 & .000 & 1.000 \\
\hline Attitudes towards training & 157 & -3.57226 & 1.80231 & .000 & 1.000 \\
\hline $\begin{array}{l}\text { Self-confidence in } \\
\text { integrating ICT }\end{array}$ & 175 & -3.66327 & 1.84529 & .000 & 1.000 \\
\hline $\begin{array}{l}\text { Digital literacy and ICT } \\
\text { acceptance }\end{array}$ & 190 & -3.22269 & 2.78879 & .000 & 1.000 \\
\hline $\begin{array}{l}\text { I think my level of digital } \\
\text { literacy is: }\end{array}$ & 195 & -2.46686 & 2.69942 & .000 & 1.000 \\
\hline $\begin{array}{l}\text { Attributes of ICT } \\
\text { acceptance in teaching }\end{array}$ & 176 & -2.58021 & 2.01293 & .000 & 1.000 \\
\hline Valid N (listwise) & 140 & & & & \\
\hline
\end{tabular}

It is evident that most of them had a basic understanding in using ICTs in Education but they have not integrated these ICTs into their classrooms yet. As more than half $(53 \%)$ of the teachers completely agreed that the tablet computer is a valuable tool for educators and $49 \%$ completely agreed that tablet computers will change the way they teach, one will then determine if this was the case during the post baseline assessment.

Another significance is the attitude of the teachers towards technology. In the interviews it was revealed that themes on assistance of the tablets to teachers and their learners were very strong. The following are a few qualitative feedbacks: 'The use of the tablet computer as a learning tool excites me'; 'The tablet computer helps me to teach in more effective ways', 'The tablet computer can help my learners to learn because it allows them to express their thinking in better and different ways'; and 'The tablet can assist my learners to understand concepts in more effective ways'. I expect to find ICT useful in my teaching work'; 'Using ICT will enable me to exercise my teaching work easier'; 'Using ICT will enable me to positively teach more learners'; 'I intend to continue using ICT for my teaching rather than discontinue using it'; 'My intentions are to continue using ICT for teaching rather than traditional teaching'; 'ICT use for teaching is clear and understandable'.

The post baseline assessment will therefore be used, to determine what the real impact of the project after training of the 6 training sessions have had on teacher's digital literacy levels, their adoption of technology to make it part of their teaching and learning and finally on their overall perception and motivation to use the technology in future. The feedback on whether teachers have formed communities of practices amongst themselves and between various schools, will also be important to determine as this will also provide input into the impact of this project on the various communities in the various clusters. Based on this project the total no of learners who were affected is 6895 (Boys $=3346$ Girls $=3549$ ). 


\section{CONCLUSION}

The results provided by the teachers before commencing training on how to use and integrate mobile technology into their classrooms revealed that they feel challenges regarding solving technical difficulties. The baseline indicated that almost two-thirds (63\%) of them were not able to solve their own technical problems, while $57 \%$ of the teachers believed that they did not have good ICT skills. More than half $(52 \%)$ of the teachers did not know a lot about different technologies. The advantages were that the teachers did had prior exposure to basic introduction to computers and some word processing knowledge. They are also positive about what difference the use of the mobile technology can have for both themselves and their learners.

\section{ACKNOWLEDGEMENT}

This paper acknowledge the funding support of the National Research Foundation (NRF) in South Africa with grant number: 112252. It also acknowledges the DRDLR ICT4E Project which is funded by the DRDLR and where the UFS provides the training of the teachers in every school.

\section{REFERENCES}

Adukaite, A., Van Zyl, I., Er, Ş. \& Cantoni, L. 2017. Teacher perceptions on the use of digital gamified learning in tourism education: The case of South African secondary schools. Computers \& Education, 111:172-190.

Ally, M. 2009. Mobile learning : transforming the delivery of education and training. Edmonton: AU Press.

Bates, T., Swennen, A. \& Jones, K. 2014. The professional development of teacher educators. Routledge.

Blackwell, J., Sheridan, J., Instone, K., Schwartz, D.R. \& Kogan, S. 2009. Design and adoption of social collaboration software within businesses. Proceedings of the 27th international conference extended abstracts on Human factors in computing systems. Boston, MA, USA.

Botha, A. \& Herselman, M. 2015. A Teacher Tablet Toolkit to meet the challenges posed by 21 st century rural teaching and learning environments. South African Journal of Education, 35(4):19.

Botha, A. \& Herselman, M. 2016. Rural teachers as innovative cocreators: An intentional Teacher Professional Development strategy. ConfIRM 2015. Cape Town, South Africa.

Botha, A. \& Herselman, M. 2018. Teachers become cocreators through participation in a teacher professional development (TPD) course in a resource constraint environment in South Africa. The Electronic Journal of Information Systems in Developing Countries, 84(1):e12007.

Botha, A., Herselman, M., Musgrave, S. \& Jaeschke, G. 2017. Dimensional evaluation of a rural mobile learning teacher professional development curriculum.

Chiu, T.K. \& Churchill, D. 2016. Adoption of mobile devices in teaching: Changes in teacher beliefs, attitudes and anxiety. Interactive Learning Environments, 24(2):317-327.

Creswell, J.W. \& Clark, V.L.P. 2017. Designing and conducting mixed methods research. Sage publications.

Creswell, J.W., Hanson, W.E., Clark Plano, V.L. \& Morales, A. 2007. Qualitative research designs: Selection and implementation. The counseling psychologist, 35(2):236-264.

Creswell, J.W. \& Poth, C.N. 2017. Qualitative inquiry and research design: Choosing among five approaches. Sage publications.

D'aiglepierre, R., Aubert, A. \& Loiret, P. 2017. How digital technology can help reinvent basic education in Africa. The Conversation, [Online]. Available: https://theconversation.com/how-digital-technology-can-help-reinvent-basiceducation-in-africa-85937 [Accessed 30 May 2018].

Department of Basic Education. 2004. White paper on E-Education: Transforming learning and teaching through information and communication technologies. [Online]. Available: http://www.education.gpg.gov.za/Legislation/White\%20paper\%207\%20on\%20e-Education.pdf [Accessed.

Department of Basic Education. 2007. Guideline for Teacher Training and Professional Education in ICT. [Online]. Available.

Department of Basic Education. 2012. Action Plan 2014: Towards the realisation of schooling 2025. [Online]. Available: http://www.education.gov.za/LinkClick.aspx?fileticket=zpM1hJi8qDs=\&tabid=418\&mid=1211 [Accessed June]. 
Department of Education 2004. White Paper on e-Education: Transforming Learning and Teaching through Information and Communication Technologies (ICTs). In: Department of Education (ed.). Pretoria: South African Government Gazette.

Ekanayake, S.Y. \& Wishart, J. 2014. Integrating mobile phones into teaching and learning: A case study of teacher training through professional development workshops. British Journal of Educational Technology:n/a-n/a.

Ertmer, P.A., Ottenbreit-Leftwich, A.T., Sadik, O., Sendurur, E. \& Sendurur, P. 2012. Teacher beliefs and technology integration practices: A critical relationship. Computers \& Education, 59(2):423-435.

Fu, Q.-K. \& Hwang, G.-J. 2018. Trends in mobile technology-supported collaborative learning: A systematic review of journal publications from 2007 to 2016. Computers \& Education.

Haßler, B., Major, L. \& Hennessy, S. 2016. Tablet use in schools: A critical review of the evidence for learning outcomes. Journal of Computer Assisted Learning, 32(2):139-156.

Hwang, G.-J., Chu, H.-C. \& Lai, C.-L. 2017. Prepare your own device and determination (PYOD): a successfully promoted mobile learning mode in Taiwan. International Journal of Mobile Learning and Organisation, 11(2): $87-107$

Khumalo, B., Molepo, G. \& Mji, A. 2015. Perceptions of school principals on the challenges arising from unavailability of information and communication technologies (ict) in rural South African schools. Rethinking Teaching and Learning in the 21st Century.

Kim, S.H., Holmes, K. \& Mims, C. 2005. Mobile Wireless Technology Use and Implementation: Opening a Dialogue on the New Technologies in Education. TechTrends, 49(3):54-64

Kotzé, T., Van Der Westhuizen, M. \& Barnard, E. 2017. Teaching strategies to support isiXhosa learners who receive education in a second/third language. South African Journal of Education, 37(3):1-12.

Kruger, H.J.J. 2015. Evaluating mobile applications that support Mathematics learning in the Further Education and Training Phase. University of Pretoria.

Kukulska-Hulme, A. 2007. Mobile usability in Educational Contexts: What have we learnt? International Review of Research in Open and Distance Learning, 8(2).

Mabila, J., Van Biljon, J. \& Herselman, M. 2017. A sustainability framework for mobile technology integration in schools: The case of resource constrained environments in South Africa.

Meyer, I., Marais, M. \& Dlamini, S. 2016. Framework for assessing implementation readiness in ICT4E projects. Unpublished framework document, CSIR Meraka Institute, Pretoria, South Africa.

Mouton, J. 2006. How to Succeed in Your Master's and Doctoral Studies: A South African Guide and Resource Book. Pretoria: Van Schaik.

Naiman, L. 2016. Design thinking as a strategy for innovation.: Creativity at work. [Online]. Available: http://www.creativityatwork.com/design-thinking-strategy-for-innovation/ [Accessed.

National Planning Commision. 2011. National Development Plan: Vision for 2030. South Africa.

Nvivo. 2017. Homepage. [Online]. Available: https://www.qsrinternational.com/ [Accessed 31 January].

Oecd 2018. The future of education and skills: Education 2030.

Ramorola, M.Z. 2018. Transforming teaching and learning through technology integration.

Rikkerink, M., Verbeeten, H., Simons, R.-J. \& Ritzen, H. 2016. A new model of educational innovation: Exploring the nexus of organizational learning, distributed leadership, and digital technologies. Journal of Educational Change, 17(2):223-249.

Şad, S.N. \& Göktaş, Ö. 2014. Preservice teachers' perceptions about using mobile phones and laptops in education as mobile learning tools. British Journal of Educational Technology, 45(4):606-618.

Smore. 2016. Digital Badging. [Online]. Available: https://www.smore.com/y0fg0-digital-badging [Accessed.

Teo, T., Lee, C.B. \& Chai, C.S. 2008. Understanding pre-service teachers' computer attitudes: applying and extending the technology acceptance model. Journal of Computer Assisted Learning, 24:128-143.

Terhoven, R. \& Fataar, A. 2018. The role of leadership practices in establishing a curriculum policy platform at working-class schools. South African Journal of Education, 38(2):1-10.

Thornton, P. \& Houser, C. 2005. Using mobile phones in English education in Japan. Journal of Computer Assisted Learning, 21(3):217-228.

Unicef. 2017. Innovation in Education. [Online]. Available: https://www.unicef.org/education/bege_73537.html [Accessed 12 March].

Vandeyar, T. 2010. The appropriation of education policy on information and communication technology in South African schools. Pretoria, South AFrica: University of Pretoria.

Vosloo, S. 2010. Book-Poor, but Mobile Phone-Rich? Look to M-Novels. South Africa: Shuttleworth Foundation Trust. 